\title{
Synthesis of Bacterial Flagella
}

\section{Requirement for Protein and Ribonucleic Acid Synthesis During Flagellar Regeneration in Bacillus subtilis}

\author{
K. DIMMITT, S. BRADFORD, AND M. SIMON \\ Department of Biology, University of California, San Diego, and Department of Biology, Revelle College, \\ La Jolla, California 92037
}

Received for publication 26 December 1967

\begin{abstract}
A relatively simple immunochemical procedure for estimating flagellar protein was developed. This procedure involved measuring the binding of purified, radioactively labeled, antiflagellar antibodies to bacteria. The assay was used to determine the requirements for ribonucleic acid (RNA) and protein synthesis during flagellar regeneration in Bacillus subtilis. Immediate inhibition of flagella development was observed when chloramphenical or puromycin was added to cells. This inhibition indicated the absence of a large pool of flagella precursors that could be assembled in the absence of protein synthesis. When the cells were starved for uracil or treated with actinomycin D to inhibit RNA synthesis, the ability of the cells to regenerate flagella decayed with a half-life of $5.5 \mathrm{~min}$. When B. subtilis auxotrophs were starved for tryptophan, they continued to synthesize flagella, although this process was also inhibited by actinomycin D. On the basis of these results, we concluded that (i) the system involved in flagellar regeneration does not have unusual metabolic stability, (ii) regeneration requires both concomitant protein and RNA syntheses, and (iii) $B$. subtilis continues to synthesize messenger RNA during tryptophan starvation.
\end{abstract}

The synthesis of bacterial flagella has been studied with a view toward understanding the mechanisms involved in the formation of subcellular organelles. In general, experimental manipulations involve shearing the bacteria to detach the flagellar filament and resuspending the cells in growth medium to allow regeneration (11, $12,19)$. Studies of the physiological requirements for regeneration have led to the suggestion that a metabolically stable messenger ribonucleic acid (mRNA) mediates the synthesis of the major component of flagella, flagellin $(15,16)$. This notion is supported by the observation that both Bacillus subtilis and Salmonella typhimurium regenerate flagella when the cells are deprived of tryptophan. Although tryptophan is not found in the flagellin protein, it is thought that this substance is necessary for RNA synthesis, since uracil incorporation into RNA is inhibited when "stringent" cells are deprived of amino acids.

Recent studies of the control of RNA synthesis $(3,7)$ indicate that inhibition of uracil incorporation reflects the inhibition of the cell's ability to use exogenously supplied pyrimidine precursors. In fact, there is evidence that, although net RNA synthesis is inhibited, mRNA continues to turn over during amino acid starvation (17). Therefore, we reexamined the physiological requirements for flagellar regeneration.
In this investigation, we conducted experiments to determine the effects of a variety of metabolic inhibitors, as well as the effects of uracil and amino acid starvation, on flagellar regeneration. These experiments indicate that the system involved in flagellar regeneration does not have unusual metabolic stability.

\section{Materials AND Methods}

Materials. ${ }^{125} \mathrm{I},{ }^{131} \mathrm{I}$, and ${ }^{3} \mathrm{H}$-uracil were obtained from the New England Nuclear Corp. (Boston, Mass.). Actinomycin D was a gift from $\mathrm{H}$. Herschman. Membrane filters (27-mm, type B-6) were obtained from Carl Schleicher and Schuell Co. (Keene, N.H.), and Whatman DE 81 filter paper was purchased from Van Waters and Rogers Co. (San Francisco, Calif.). Bovine serum albumin and rabbit $\gamma$-globulin were obtained from the Pentex Corp. (Kankakee, Ill.).

The buffers used in the immunological assays were isosatris, containing $0.14 \mathrm{M}$ sodium chloride, $0.01 \mathrm{M}$ $(p \mathrm{H}$ 7.45) tris(hydroxymethyl)aminomethane (Tris; Sigma Chemical Co., St. Louis, Mo.), $5 \times 10^{-4} \mathrm{M}$ magnesium sulfate, $1.5 \times 10^{-4} \mathrm{M}$ calcium chloride, and $0.1 \%$ bovine serum albumin; and iso-RGG, composed of isosatris and $200 \mu \mathrm{g}$ of rabbit $\gamma$-globulin per ml.

The $B$. subtilis strains used in this study were BR 13 (trp- ura $\left.^{-}\right)$, BR 72 (trp- ura $a^{-}$), and BR 44 (trp- leu- ${ }^{-}$). These strains were obtained by mutation from 168 $\left(t r p^{-}\right)$by B. Rielly, Scripps Clinic Research Founda- 
tion, La Jolla, Calif. N. Sueoka (Princeton University, Princeton, N.J.) prepared $168\left(t r p^{-} l y s^{-}\right)$and 168 $\left(\right.$ trp $^{+}$phe $\left.e^{-} l y s^{-}\right)$. B. subtilis $23 \mathrm{~W}$ is a prototroph derived from the classical $B$. subtilis 23 strain, and $168 \mathrm{M}$ is a highly transformable strain derived from 168 $\left(t r p^{-}\right)$. SB $108\left(f a^{-}\right)$, which is nonmotile and lacks flagella, was sent to us by Dr. Nester, Stanford University, Palo Alto, Calif.

The cells were grown in either Penassay Broth or minimal medium (18) supplemented with $0.1 \%$ Casamino Acids and $15 \mu \mathrm{g}$ of required nutrients per $\mathrm{ml}$. For the regeneration experiments, cultures were grown overnight, diluted into fresh medium, and allowed to grow for $2 \mathrm{hr}$. The regeneration time in minimal medium was usually 50 min.

Purification of antigens and antibodies. Flagella were prepared from B. subtilis 168 (trp $^{+}$phe lys $^{-}$) and $B$. subtilis $23 \mathrm{~W}$. The bacteria were grown overnight on nutrient agar in pans. The cells were harvested and the flagella were purified by a modification of the procedures described by Abram and Koffler (1) and Martinez (14). The cells were sheared in an omnimixer (Virtis Co., Inc., Gardiner, N.Y.) for $30 \mathrm{sec}$ at $9,000 \mathrm{rev} / \mathrm{min}$ to remove the flagella. The bacteria were separated by low-speed centrifugation, and the flagella in the supernatant fluid were collected by centrifugation at $100,000 \times g$ for $1 \mathrm{hr}$. The pellet was gently resuspended in $0.01 \mathrm{M}$ phosphate buffer at $p \mathrm{H}$ 6.8. The resuspended material was precipitated at $4 \mathrm{C}$ with $50 \%$ ammonium sulfate. The precipitate

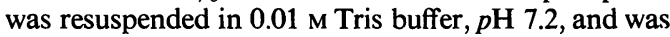
dialyzed against $0.01 \mathrm{M}$ Tris buffer, $p \mathbf{H} 7.2$, containing $0.05 \mathrm{M}$ sodium chloride. After extensive dialysis, this material was applied to a column of Ecteola ion exchange resin and was developed with a continuous gradient of 0.01 to $1.0 \mathrm{M}$ sodium chloride. The antigenic activity was eluted at about $0.3 \mathrm{M}$ sodium chloride. This material gave a single band when subjected to electrophoresis (at $p \mathrm{H} 2.0$ and $p \mathrm{H} 8.5$ ) in $8.0 \mathrm{~m}$ urea.

Antisera were prepared by a series of intravenous injections of $1 \mathrm{mg}$ of purified flagella. The rabbits were bled 1 week after the last injection.

The purified antibody was prepared by the procedure of Freedman, Slobin, Robbins, and Sela (6). An immune precipitate was formed in antibody excess. The precipitate was washed with $0.15 \mathrm{M}$ sodium chloride and $0.01 \mathrm{M}$ phosphate buffer. It was then dissolved in deionized, $8 \mathrm{M}$ urea and passed through a column of diethylaminoethyl (DEAE)-cellulose equilibrated with deionized urea and $0.01 \mathrm{M}$ Tris buffer, $p \mathrm{H}$ 7.2. The initial protein-containing fractions emerging from the column were pooled and dialyzed exhaustively against $0.01 \mathrm{M}$ phosphate, $p \mathbf{H} 6.8$, containing $0.1 \mathrm{M}$ sodium chloride. The antibody was then centrifuged to remove any precipitate and was stored at $-20 \mathrm{C}$. Approximately $40 \%$ of the total antibody activity of the initial serum was recovered in this way.

The purified antibody was iodinated by the procedures described by Greenwood (9). One preparation was made with ${ }^{131} I$, whereas later preparations utilized ${ }^{125} \mathrm{I}$. The specific activity of the antibody was generally in the range of 0.1 to $1.0 \mu \mathrm{c}$ of antibody per $\mu \mathrm{g}$. The $\beta$ emmission from ${ }^{131}$ I was measured on a gas-flow counter (Nuclear-Chicago Corp., Des Plaines, Ill.), and ${ }^{125}$ I was counted by scintillation in liquifluor scintillation fluid (Nuclear-Chicago Corp.). The ${ }^{125}$ Ilabeled sera could be used over a period of 3 to 4 months.

Ferritin-conjugated antibodies were prepared by the method of Dutton, Adams, and Singer (2). The antibody was added to a suspension of cells in growth medium, and the mixture was incubated for $5 \mathrm{~min}$ at room temperature. The cells were resuspended in 0.1 M ammonium acetate or distilled water and were put directly on copper grids for electron microscopy.

Flagella determination. The cell density was estimated on the basis of measurements of the turbidity of the culture. The cells were removed from the growth medium by centrifugation and were resuspended in buffer. The measurements could also be made directly in growth medium when $10^{-2} \mathrm{M}$ potassium cyanide or $50 \mu \mathrm{g} / \mathrm{ml}$ of chloramphenicol (CAP) was added to inhibit further development of flagella. The bacteria were diluted with isosatris buffer to appropriate concentrations. A $0.1-\mathrm{ml}$ amount of antibody was added to $1.0 \mathrm{ml}$ of bacteria, and, after gentle mixing, the tubes were incubated at room temperature for $30 \mathrm{~min}$. They were then chilled at $4 \mathrm{C}$, and $1.0 \mathrm{ml}$ of cold iso-RGG buffer was added. Filters (Millipore Corp., Bedford, Mass.) were prepared by soaking in iso-RGG buffer and washing with $4.0 \mathrm{ml}$ of the buffer. The sample was then poured on the filter and washed four times with $4.0 \mathrm{ml}$ of buffer. It was essential to minimize the amount of air passing through the filter, since the air appeared to denature some of the antibody and consequently increase the level of nonspecific binding to the filter. The filters were dried, immersed in scintillation fluid, and counted.

\section{RESULTS}

Antibody binding to flagellated bacteria. The electron micrograph of ferritin-conjugated antiflagellar antibody binding (Fig. 1E) illustrates the polydeterminant nature of the flagellum. When excess ferritin-antibody was added to the cells, an average of one antibody was bound for each $45 \mathrm{~A}$ of length. Therefore, a flagellum $9 \mu$ long would have at least 2,000 antigenic determinant sites. The pictures also illustrate the specificity of the antiflagellar sera. The two strains shown, B. subtilis $23 \mathrm{~W}$ and $168 \mathrm{M}$, are both motile. However, their flagella are distinct antigens (5). There is no significant amount of ferritinanti-168 bound to $B$. subtilis 23 , and the 23 antibody does not bind to 168 flagella (Fig. 1A, B, C, D).

Under conditions where the available binding sites are saturated with antibody, the amount of antibody bound should be a direct measure of the flagella protein on the bacteria. To measure binding conveniently, the antibodies were purified and iodinated. The radioactive antibody was added to bacteria and the mixture was passed through a Millipore filter to collect the cells and 

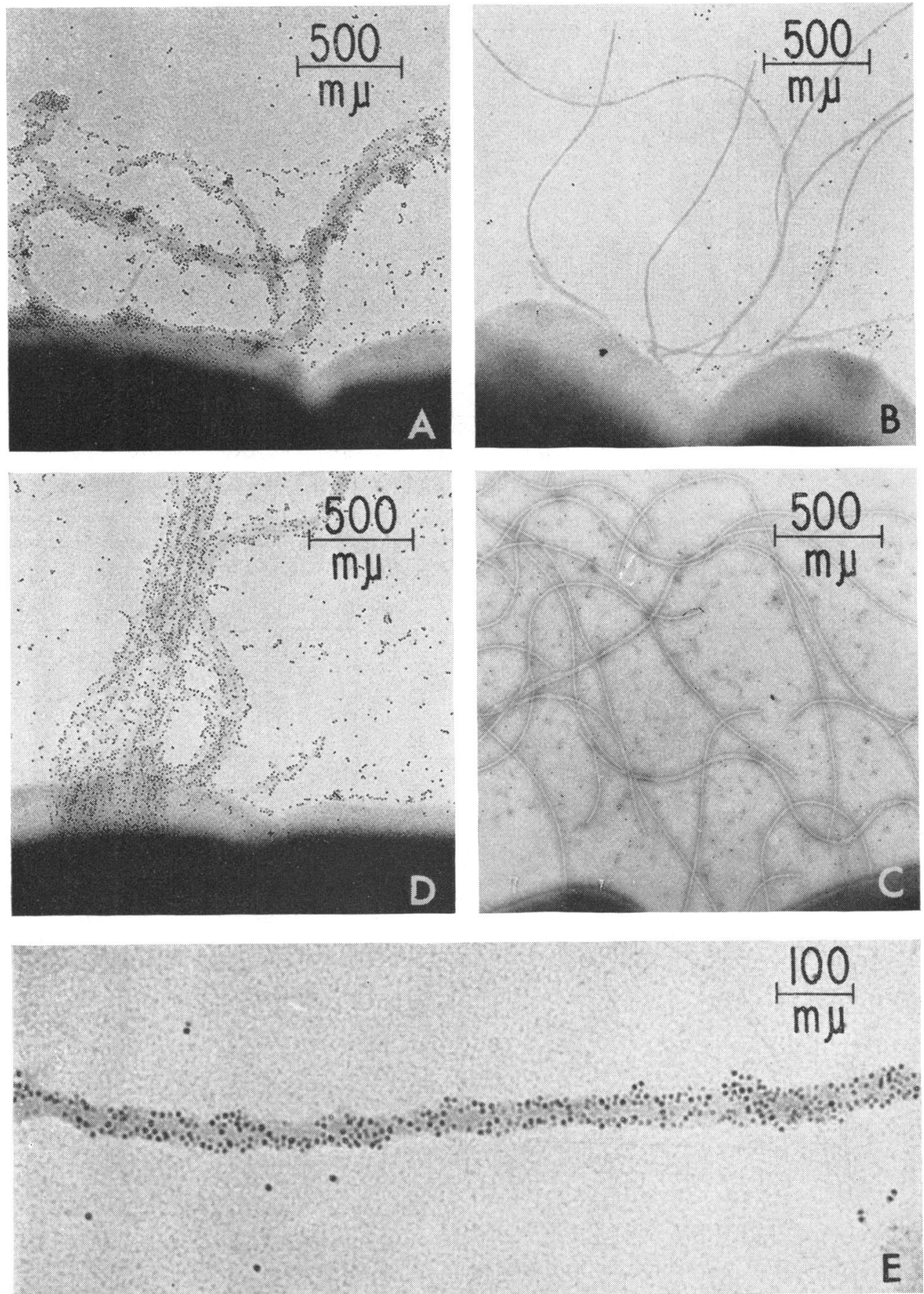

Fig. 1. Reaction of flagella with ferritin-conjugated antibody. $(A)$ Bacillus subtilis $168 M$ and anti-168. $\times$ 30,000. (B) B. subtilis 23 and anti-168. $\times 30,000 .(C)$ B. subtilis $168 M$ and anti-23. $\times 30,000$. (D) B. subtilis 23 and anti-23. $\times 30,000 .(E) B$. subtilis 23 flagella and anti-23. $\times 110,000$. 


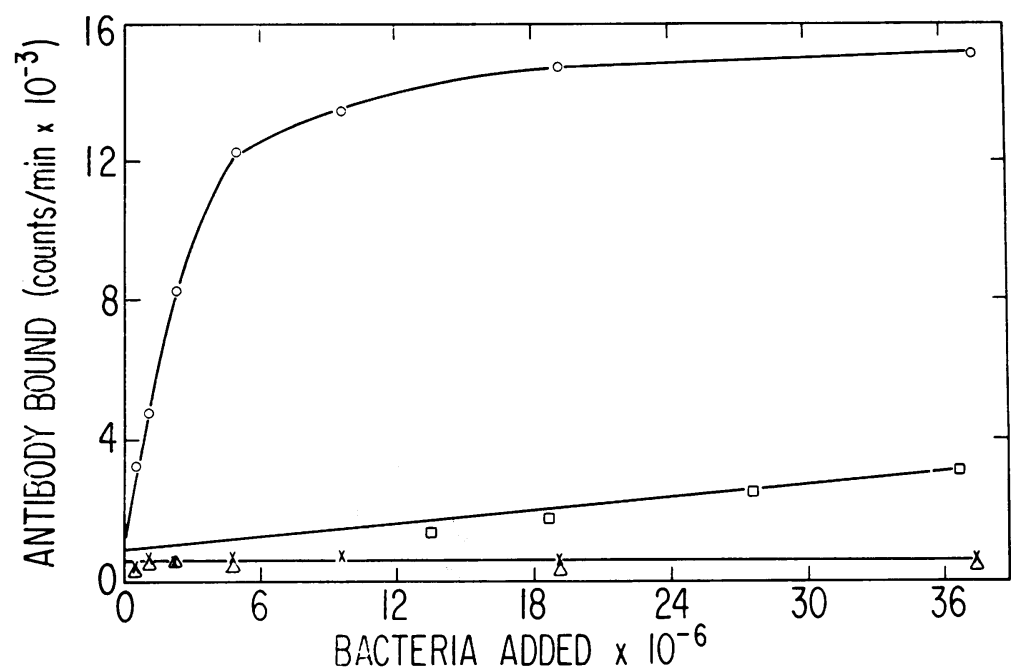

FIG. 2. Specificity of binding of iodinated antibody. Samples were removed from cultures in the exponential growth phase, and binding was measured as described in the Materials and Methods section using ${ }^{131} I$, labeled antibody. O, B. subtilis $168 \mathrm{M} ; \square, B$. subtilis $168 \mathrm{M}$, sheared; $\triangle, B$. subtilis $23 ; \times, S B 108$.

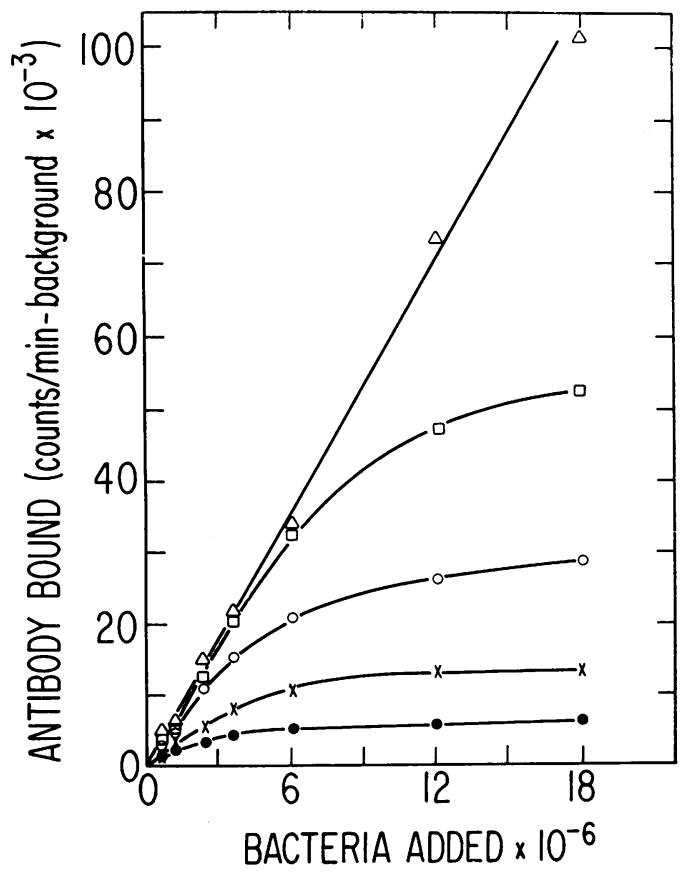

FIG. 3. Relationship of binding to antibody and antigen concentration. B. subtilis 168 (lys trp $\left.^{-}\right)$was grown in supplemented minimal medium. The cells were removed during the exponential growth phase and were diluted in buffer to the appropriate concentrations. Binding was measured at: $0,1: 200 ; \times, 1: 100 ; 0$, $1: 50 ; \square, 1: 25 ;$ and $\triangle, 1: 10$ dilutions of the purified ${ }^{125}$ I-labeled anti-168 antibody. This preparation of antibody was used in other experiments at a 1:25 dilution.

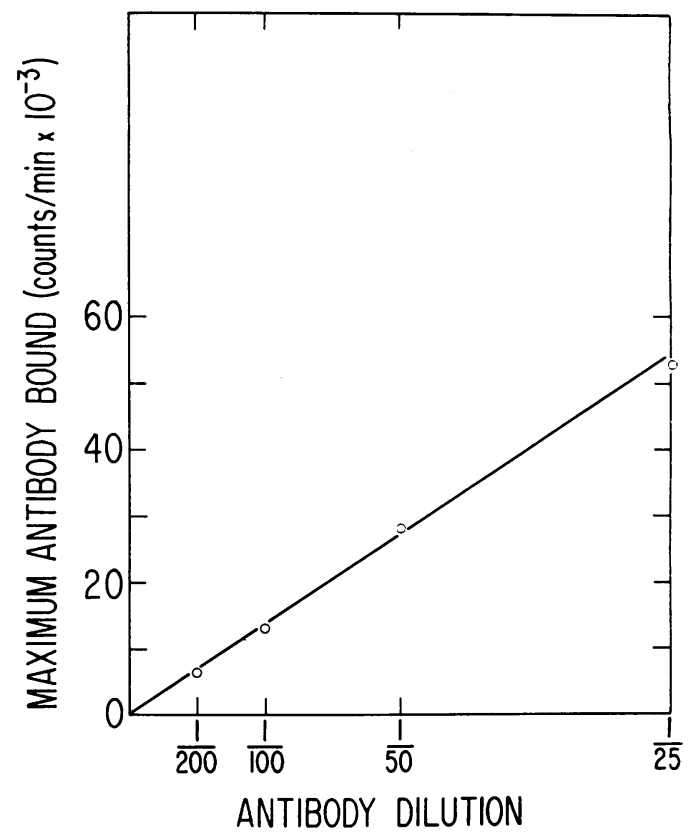

FIG. 4. Maximal amount of antibody bound at various antibody concentrations (see Fig. 3).

remove free antibody. The specificity of binding is shown in Fig. 2. When increasing amounts of fully flagellated $B$. subtitis 168 were added to the reaction mixture, the amount of antibody bound increased and then reached a maximum representing $80 \%$ of the total radioactivity. After the 


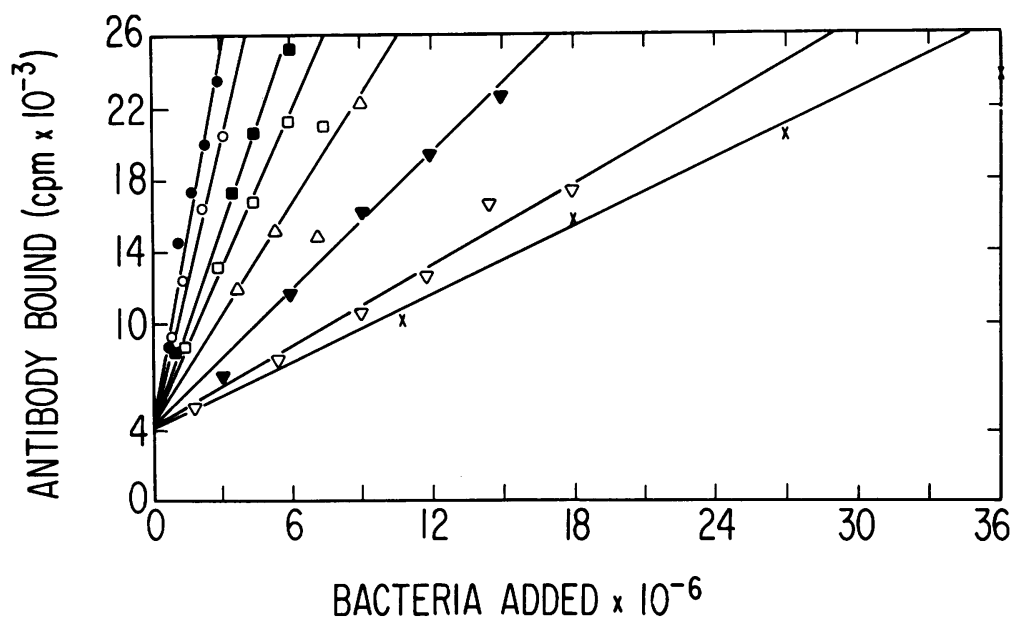

FIG. 5. Kinetics of flagella regeneration. B. subtilis 168 (lys ${ }^{-}$typ $\left.^{-}\right)$were tested for their ability to bind antiflagella antibody. Symbols: $\bigcirc$, before shearing; $\times, 1 ; \nabla, 10 ; \nabla, 16 ; \triangle, 32 ; \square, 50 ; \square, 65 ;$ and $\bigcirc, 80$ min after shearing.

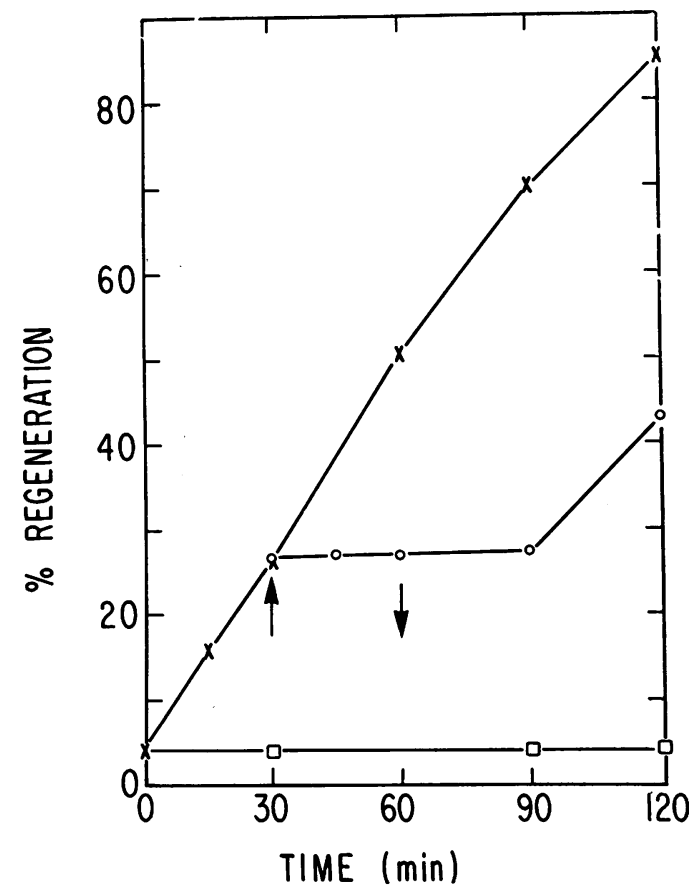

Fig. 6. Effect of $C A P$ on flagella regeneration. An exponentially growing culture of $B$. subtilis 168 (trp ${ }^{+}$ phe ${ }^{-}\left(y s^{-}\right)$was sheared and resuspended in fresh Penassay Broth. The culture was divided into three parts and was incubated with gentle shaking at 37 C. Samples were removed and the degree of flagella regeneration was measured. Symbols: $\times$, no additions; $\square, C A P$ $(100 \mu \mathrm{g} / \mathrm{ml})$ was added immediately after shearing; $O$, CAP $(100 \mu \mathrm{g} / \mathrm{ml})$ was added after $30 \mathrm{~min}$ of incubation. After $60 \mathrm{~min}$, the cells were washed free of CAP by centrifugation and were resuspended in fresh medium. bacteria were sheared, the amount of antibody per bacterium decreased to about $3 \%$ of the fully flagellated cells. This residual binding was probably due to unsheared portions of flagella which remained on the bacteria. There was no 168 antibody bound to the nonflagellated mutant SB 108 or to $B$. subtilis $23 \mathrm{~W}$.

To determine the conditions necessary for the use of antibody to estimate flagella protein, we examined the relationship of binding to antigen and antibody concentration (Fig. 3, 4). At relatively high concentrations of bacteria, most of the available antibody was combined with flagella, and binding was proportional to antibody concentration (Fig. 4). However, at low antigen concentration, when there was a great excess of antibody, binding was directly proportional to antigen and independent of antibody concentration. The initial slope of the binding curve therefore reflects the relative amount of flagella protein per cell.

The results of an experiment designed to follow the kinetics of flagellar regeneration are shown in Fig. 5. The bacteria were sheared and centrifuged to remove detached flagella. They were resuspended in growth medium and were agitated gently at $37 \mathrm{C}$. Samples were removed at various times, resuspended in buffer, and antibody binding was measured. The slopes of the binding curves increased with time of incubation. The percentage of regeneration can be calculated by dividing the slope of the curve obtained at any time during regeneration by the slope of the curve found for fully flagellated cells before shearing. A comparison of measurements made 


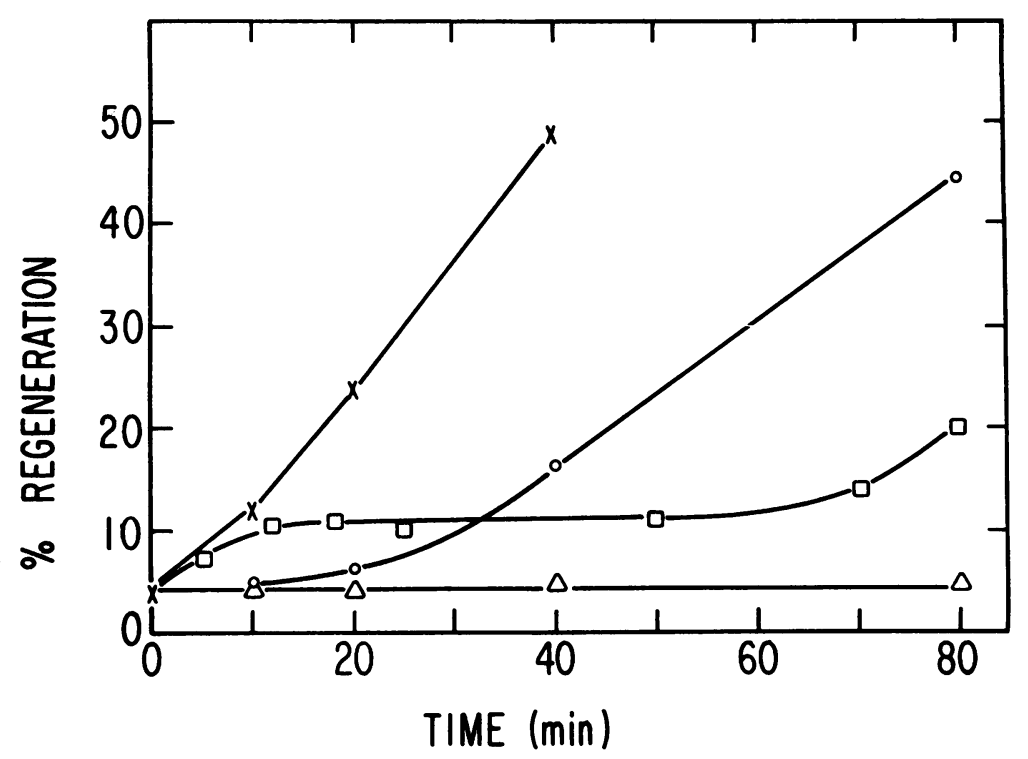

FIG. 7. Effect of uracil starvation on flagella regeneration. BR 13 (trp- ura $\left.{ }^{-}\right)$was grown in supplemented minimal medium. The cells were resuspended in minimal medium in the absence of uracil. Half of the culture was incubated in the absence of uracil for $10 \mathrm{~min}$ at $37 \mathrm{C}$ and then was sheared and resuspended in the absence of uracil $(\triangle)$ and in the presence of $15 \mu \mathrm{g} / \mathrm{ml}$ of uracil $(\mathrm{O})$. The other half of the culture was immediately sheared and resuspended in the presence of $15 \mu \mathrm{g} / \mathrm{ml}$ of uracil $(X)$ and in the absence of uracil ( $\square)$. After 50 min of incubation, uracil $(15 \mu \mathrm{g} / \mathrm{ml})$ was added to the last culture.

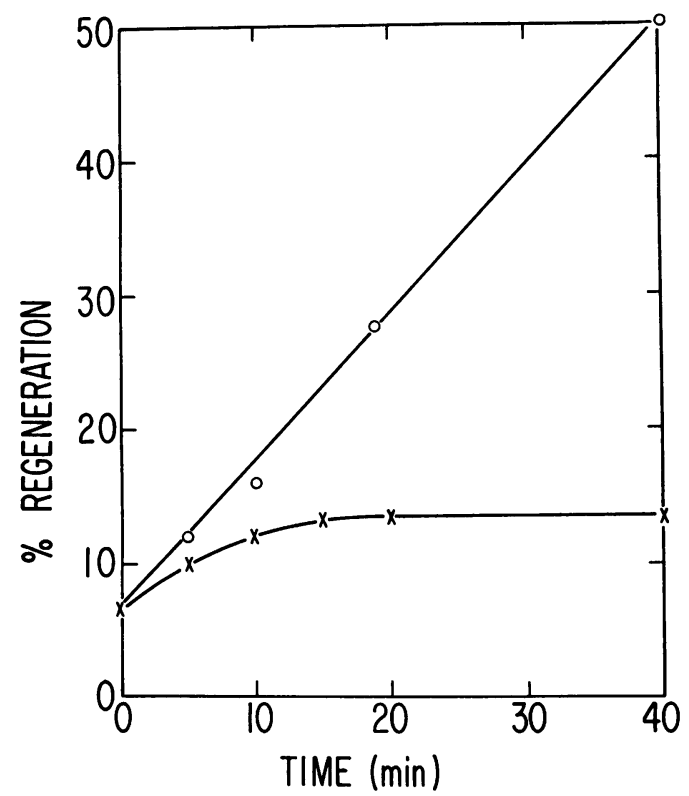

FIG. 8. Effect of actinomycin $D$ on flagella regeneration in B. subtilis 168 (trp ${ }^{+}$phe $^{-}$lys $\left.^{-}\right)$. The cells were sheared and half of the culture was resuspended in minimal medium containing $5 \mu \mathrm{g} / \mathrm{ml}$ of actinomycin $D$ $(X)$ and the other half of the culture was resuspended in minimal medium (O). by this and related methods with results obtained by conventional serological techniques was presented in another publication (8).

Requirement for protein synthesis. The assay described above was used to examine the effects of specific metabolic inhibitors on flagellar regeneration. The addition of $100 \mu \mathrm{g}$ of CAP per $\mathrm{ml}$ resulted in an immediate cessation of flagella synthesis (Fig. 6). When the cells were washed free of CAP, regeneration resumed after a lag of about $30 \mathrm{~min}$. In other experiments using a wide variety of $B$. subtilis strains, immediate inhibition by CAP was observed in minimal medium at a concentration of $30 \mu \mathrm{g} / \mathrm{ml}$ when the cells were deprived of tryptophan. Furthermore, the addition of $60 \mu \mathrm{g}$ of puromycin per $\mathrm{ml}$ led to similar results, whereas bacteriostatic concentrations of mitomycin $\mathrm{C}$ did not have a marked effect on the rate of regeneration. On the basis of these experiments, we can conclude that concomitant protein synthesis is required for flagellar regeneration.

Requirement for RNA synthesis. In initial experiments, uracil starvation was used to inhibit RNA synthesis. When uracil-requiring bacteria were starved for $10 \mathrm{~min}$ and then were sheared and resuspended in the absence of uracil, there was no regeneration (Fig. 7). If uracil was added to the medium, synthesis resumed after a lag of $15 \mathrm{~min}$. When the cells were sheared and 


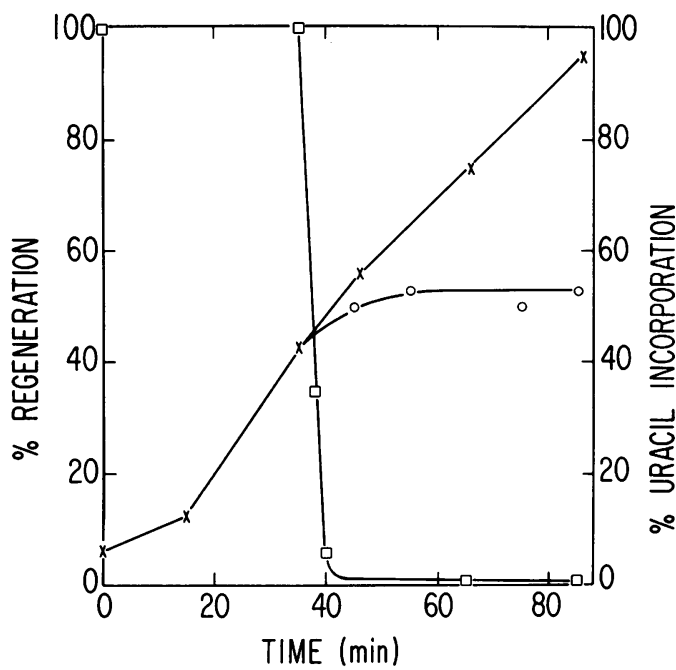

FIG. 9. Effect of actinomycin on flagella regeneration in B. subtilis 23. The cells were sheared and resuspended in minimal medium. After 35 min of incubation, part of the culture was transferred to a flask containing actinomycin $D$. The final concentration of actinomycin was $1 \mu \mathrm{g} / \mathrm{ml}$. Uracil incorporation was measured by removing 2.0-ml samples from the culture, and incubating these samples with $1 \mu \mathrm{c}$ of ${ }^{3} \mathrm{H}$-uracil (200 $\mu \mathrm{c} / \mu \mathrm{mole})$ for $2.5 \mathrm{~min}$. An equal volume of cold trichloroacetic acid was added, and the cells were washed on Millipore filters with $20 \mathrm{ml}$ of $5 \%$ trichloroacetic acid containing $50 \mu \mathrm{g} / \mathrm{ml}$ of unlabeled uracil. Symbols: $\times$, no actinomycin; $O, 1 \mu \mathrm{g}$ of actinomycin per $\mathrm{ml} ; \square$, uracil incorporation. resuspended in the absence of uracil, flagellar synthesis continued for $10 \mathrm{~min}$ and then ceased. If uracil was then added to the culture, regeneration resumed after a 20-min lag. The residual synthesis observed when uracil was removed could result from the utilization of an internal pool of pyrimidine or from the decay of pre-existing messenger RNA.

Actinomycin D was used to further test the requirement for RNA synthesis. When the cells were sheared and incubated in the presence of $5 \mu \mathrm{g}$ of actinomycin D per ml, flagellar synthesis proceeded for about $10 \mathrm{~min}$ and then ceased (Fig. 8). Relatively high concentrations of actinomycin were required to inhibit RNA synthesis with $B$. subtilis 168 strains. The experiments were therefore repeated with the $23 \mathrm{~W}$ strain (Fig. 9). The addition of $1 \mu \mathrm{g}$ of actinomycin per $\mathrm{ml}$ rapidly reduced uracil incorporation to less than $1 \%$ of the control rate. Under these conditions, flagellar synthesis continued for a short period and then stopped. Similar results were obtained with actinomycin concentrations as low as $0.5 \mu \mathrm{g} / \mathrm{ml}$. The decay of the capacity of both the $23 \mathrm{~W}$ and $168 \mathrm{M}$ cells to regenerate flagella was exponential, with a half-life of $5.5 \mathrm{~min}$.

Effects of amino acid starvation. When tryptophan-requiring auxotrophs were resuspended in the absence of the amino acid, the rate of incorporation of uracil into RNA was inhibited. Under these conditions, the cells continued to regenerate flagella at $25 \%$ of the rate of an unstarved culture,

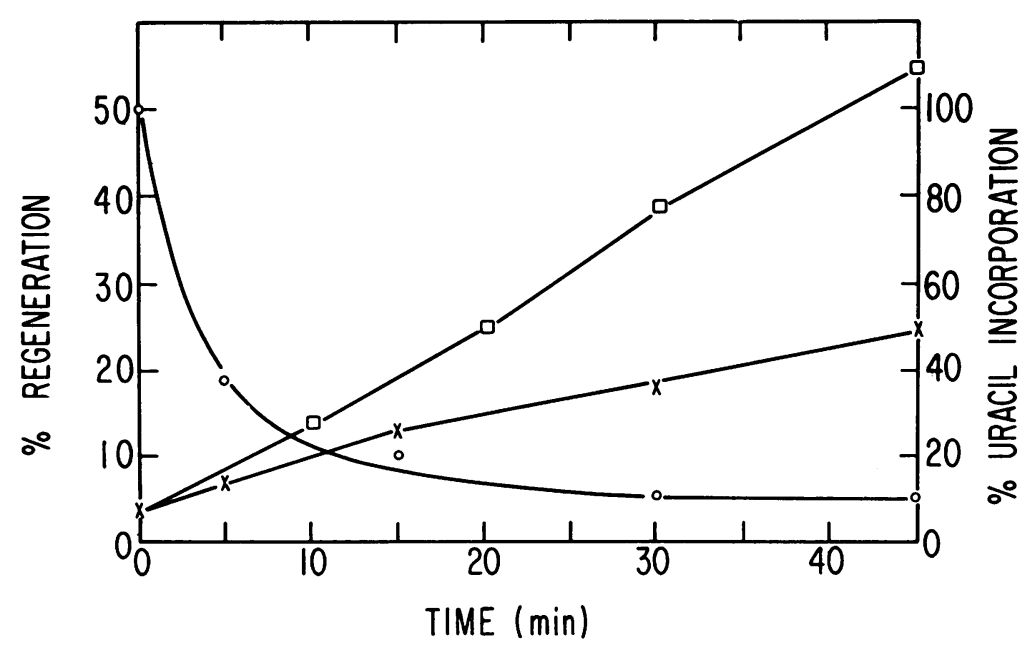

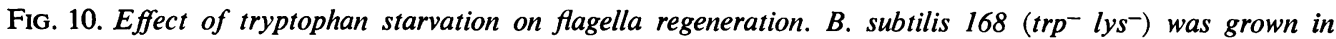
supplemented minimal medium. The cells were sheared and half of the culture was resuspended in the absence of tryptophan and the other half of the culture was resuspended in the presence of $15 \mu \mathrm{g} / \mathrm{ml}$ of tryptophan. Uracil incorporation was measured essentially by the method described in Fig. 9. Symbols: $\square$, regeneration in the presence of tryptophan; $X$, regeneration in the absence of tryptophan; $O$, uracil incorporation in the absence of tryptophan. 
even after uracil incorporation had decreased to less than $10 \%$ of the initial rate (Fig. 10). In control experiments, cells deprived of leucine showed no significant regeneration.

It is possible that, at the basal level of uracil incorporation (Fig. 10), there is sufficient RNA synthesis to maintain regeneration during amino acid starvation. To test this possibility, the cells were deprived of tryptophan for $20 \mathrm{~min}$ and then were deprived of uracil. Regeneration proceeded at exactly the same rate in the presence or absence of uracil (Fig. 11), indicating that regeneration does not depend on an external supply of RNA precursors. Therefore, either the RNA responsible for flagellar regeneration becomes unusually stable under starvation conditions (4), or the

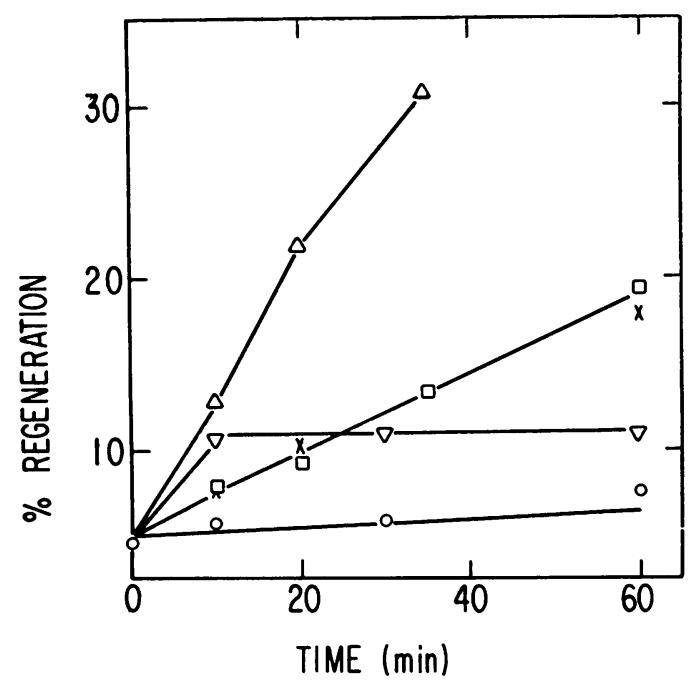

FIG. 11. Effects of consecutive tryptophan and uracil starvation on flagella regeneration. BR 72 (trp- ura-) was grown in supplemented minimal medium. The cells were resuspended in minimal medium. Part of this mixture was added to medium containing uracil but not tryptophan to starve the cells. After 20 min of incubation, the cells were sheared and resuspended in medium without tryptophan and in medium lacking both tryptophan and uracil. The remainder of the original culture was immediately sheared and resuspended in both complete medium and in minimal medium containing tryptophan but not uracil. Symbols: $\triangle$, cells grown in complete medium; $\nabla$, cells grown in medium containing 15 $\mu \mathrm{g} / \mathrm{ml}$ of tryptophan but no uracil $; \square$, cells starved and resuspended in medium containing no uracil or tryptophan; $X$, cells starved and resuspended in medium containing $15 \mu \mathrm{g} / \mathrm{ml}$ of uracil and no tryptophan. In a control experiment, BR 44 (trp- leu-) was starved for leucine for $20 \mathrm{~min}$ and then was sheared and resuspended in the absence of leucine (O). The Casamino Acids usually used to supplement the medium were replaced by a mixture of 19 amino acids; no leucine was added.
RNA continues to be synthesized and broken down (maintaining an internal pool of RNA precursors) even though net RNA synthesis is inhibited (17).

If continued RNA synthesis is required for regeneration, we would expect actinomycin $\mathrm{D}$ to inhibit the process. On the other hand, if a preexisting RNA becomes unusually stable during starvation, actinomycin $\mathrm{D}$ should have no effect. Cells were deprived of tryptophan and then were sheared and resuspended in the presence of $3 \mu \mathrm{g}$ of actinomycin $\mathrm{D}$ per $\mathrm{ml}$. The rate of regeneration decreased, and, after $10 \mathrm{~min}$, there was no further flagellar synthesis (Fig. 12). The effect of actinomycin was exactly the same when the cells were deprived of tryptophan and uracil.

\section{Discussion}

On the basis of the experiments presented here, we conclude that the process of flagellar regeneration requires both concomitant RNA and protein syntheses. Our data can be interpreted further if we assume that the limiting step in regeneration is the synthesis of flagellin subunits. When flagella are detached from exponentially growing cells, there is an excess of pre-existing sites from which new flagella can develop. The inhibition of flagella regeneration by CAP indicates that the flagellin subunits are assembled immediately after they are produced and that there is no large intracellular pool of precursor material. These

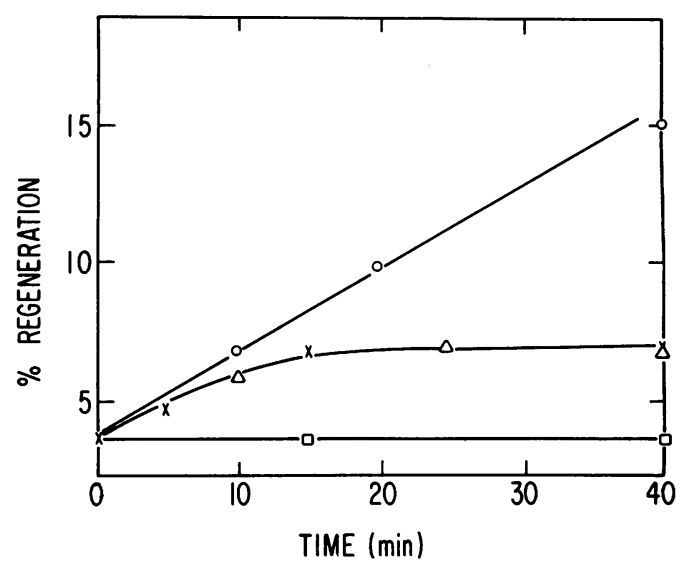

Fig. 12. Effect of actinomycin on flagellar regeneration in the absence of tryptophan. BR 72 (trp- ura-) was starved for tryptophan, as described in Fig. 11. The cells were then resuspended in medium containing: $\mathrm{O}, 15 \mu \mathrm{g} / \mathrm{ml}$ of uracil and no tryptophan; $\square, 15 \mu \mathrm{g} / \mathrm{ml}$ of uracil, no tryptophan and $50 \mu \mathrm{g} / \mathrm{ml}$ of $C A P ; \triangle, 15$ $\mu \mathrm{g} / \mathrm{ml}$ of uracil, no tryptophan, and $3 \mu \mathrm{g} / \mathrm{ml}$ of actinomycin; $X$, no uracil or tryptophan and $3 \mu \mathrm{g} / \mathrm{ml}$ of actinomycin. 
conclusions are consistent with the results obtained by Kerridge (12) in pulse-labeling experiments with $S$. typhimurium. Other workers have provided evidence for a relatively small internal pool of subunits (D. S. Nasser, Ph.D. Thesis, Purdue University, Lafayette, Ind., 1964; D. Weinstein, H. Koffler, and M. Moskowitz, Bacteriol. Proc., p. 63, 1960). Many of their experiments, however, were carried out with cultures in the stationary phase, when the bacteria do not appear to synthesize flagella.

One of the most attractive schemes available to describe the synthesis of flagella is the "factory" model. This hypothesis $(10,15)$ suggests that the basal granule of the flagellum contains a stable system involved in the synthesis and secretion of flagellin subunits. Our data argue against the existence of a metabolically stable system. The inhibition of RNA synthesis by either actinomycin or uracil starvation results in the inhibition of flagellar synthesis. The residual activity (Fig. 8), presumably due to messenger RNA decay, has a half-life of $5.5 \mathrm{~min}$, only slightly longer than that of the bulk of messenger RNA in the cell (13). Furthermore, the regeneration observed during tryptophan starvation was also dependent upon RNA synthesis, since this regeneration was inhibited by the addition of actinomycin. Our experiments suggest that amino acid starvation inhibits net RNA synthesis and the utilization of exogenously supplied uracil but does not inhibit the synthesis and degradation of mRNA.

We cannot completely eliminate the possibility that the procedures used to inhibit RNA synthesis have other primary effects on the system. However, the inhibition resulting from uracil starvation was reversed when uracil was added to the cultures (Fig. 7), and there was little change in the colony-forming ability of the cells during the course of uracil- and tryptophan-starvation experiments. Furthermore, in preliminary experiments, we found that the addition of 5-fluorouracil to cultures during regeneration resulted in the synthesis of aberrant flagellin protein (Dimmitt and Simon, unpublished data). Finally, recent experiments with $S$. typhimurium (L. Aamodt and J. Eisenstadt, Bacteriol. Proc., p. 103, 1967) indicate that an obligatory relationship between RNA synthesis and flagella regeneration exists.

The foregoing discussion was based on the assumption that the synthesis of flagellin is the limiting factor in flagellar assembly and regeneration. However, the rate of flagellin synthesis may be coupled by metabolic control mechanisms to the rate of synthesis of flagella-secreting sites. The assay that we described only measures the ap- pearance of flagellar antigens and is oblivious to the distribution of these antigens on the surface of the cell. Subsequent investigations will be devoted to a complete analysis of the kinetics of flagella elongation and initiation.

\section{ACKNOWLEDGMENTS}

We thank S. J. Singer for his help with the ferritinantibody experiments and G. Grant for providing stimulating discussions. This investigation was supported by grant GB 4153 from the National Science Foundation and by Public Health Service grant GM13210 from the National Institute of General Medical Sciences.

\section{Literature Cited}

1. Abram, D., AND H. Koffler. 1964. In vitro formation of flagella-like filaments and other structures. J. Mol. Biol. 9:168-185.

2. Dutron, A., M. Adams, AND S. J. Singer. 1966. Bifunctional imidoesters as cross-linking reagents. Biochem. Biophys. Res. Commun. 23: 730-739.

3. EdLIN, G., AND J. Neuhard. 1967. Regulation of nucleoside triphosphate pools in Escherichia coli 15. J. Mol. Biol. 24:225-230.

4. ForChHammer, J., AND N. O. KJeldgaARD. 1967. Decay of messenger RNA in vivo in a mutant of Escherichia coli 15. J. Mol. Biol. 24:459-470.

5. JoYs, T. M., AND R. W. Frankel. 1967. Genetic control of flagellation in Bacillus subtilis. $\mathbf{J}$. Bacteriol. 94:32-37.

6. Freedman, M. H., L. Slobin, J. B. Robbins, AND M. Sela. 1966. Purification of antibodies in urea. Arch. Biochem. Biophys. 116:82-90.

7. Gallant, F., and M. Cashel. 1967. On the mechanism of amino acid control of ribonucleic acid biosynthesis. J. Mol. Biol. 25:545-553.

8. Grant, G. F., AND M. SimON. 1968. Use of radioactive antibodies for characterizing antigens and application to the study of flagella synthesis. J. Bacteriol. $95: 81-86$.

9. GreenwoOd, F. C., W. M. Hunter, AND J. S. GLOVER. 1963. The preparation of ${ }^{131}$ I-labelled human growth hormone of high specific activity. Biochem. J. 89:114-123.

10. IINO, T., AND J. Lederberg. 1964. Genetics of salmonella, p. 112-142. In E. Oye [ed.], World problems of salmonellosis. The Hague.

11. KERRIDGE, D. 1959. Synthesis of flagella by amino acid requiring mutants of Salmonella typhimurium. J. Gen. Microbiol. 21:168-179.

12. Kerridge, D. 1963. Flagella synthesis in Salmonella typhimurium. the incorporation of isotopically labeled amino acids into flagellin. J. Gen. Microbiol. 33:63-76.

13. Levinthal, C., A. Kenyan, And A. Higa. 1962. Messenger RNA turnover and protein synthesis in B. subtilis inhibited by actinomycin D. Proc. Natl. Acad. Sci. U.S. 48:1631-1638. 
14. Martinez, R. J. 1963. A method for the purification of bacterial flagella by ion exchange chromatography. J. Gen. Microbiol. 33:115-120.

15. Martinez, R. J. 1966. The formation of bacterial flagella. J. Mol. Biol. 17:10-17.

16. MCClatChy, J. K., AND H. V. RiCKenBeRg. 1967. Heterogeneity of the stability of messenger ribonucleic acid in Salmonella typhimurium. $\mathbf{J}$. Bacteriol. 93:115-121.

17. Morris, D., AND J. DeMoss. 1966. Polysome transition and the regulation of RNA synthesis in Escherichia coli. Proc. Natl. Acad. Sci. U.S. 56:262-268.

18. SpIzIZEN, J. 1958. Transformation of biochemically deficient strains of $B$. subtilis by DNA. Proc. Natl. Acad. Sci. U.S. 44:1072-1078.

19. Stocker, B. A. D., AND J. Campbell. 1959. The effect of non-lethal deflagellation on bacterial motility and observations of flagellar regeneration. J. Gen. Microbiol. 20:670-685. 